\title{
Human Herpesvirus-8 Immediate-Early Region-4 Gene Locus
}

National Cancer Institute

\section{Source}

National Cancer Institute. Human Herpesvirus-8 Immediate-Early Region-4 Gene Locus. NCl Thesaurus. Code C128302.

A leftward transcribed region of the human herpesvirus- 8 genome containing the immediate early genes ORF48 and ORF29b. 